\title{
KAJIAN YURIDIS ANGGARAN DISABILITAS DALAM KEUANGAN NEGARA
}

\section{The Juridical Assessment of Disability Budgets in the Financial State}

\author{
B. Hengky Widhi A \\ Y. Sri Pudyatmoko \\ Universitas Atma Jaya Yogyakarta \\ email: bian_law@ymail.com
}

\begin{abstract}
This study is departed from the idea that the provision of budget for the persons with disability is a very important thing. Recalling this problem, a good regulation is required. This study raised a problem of the urgency of budgeting for the persons with disability and the funding strategy as well as the juridical strategy in governing the budget for the persons with disability. This study employed a juridical analytical method, a research which is conducted to analyze certain provision of law to be used later in answering the society' problem. From the research, it could be found that the provision of fund to provide the infrastructures for the persons with disability is very urgent. Such urgency included the reasons concerning the funding provision for the persons with disability and the determination of their needs required the funding provision. The budgeting strategy for the persons with disability is highly dependent on who is responsible for the affairs concerning the persons with disability. In the context of the relationship division between Central Government and Local Government, it includes those decentralized to local areas. For that reason, the local areas could provide it from Local Original Income (PAD) deriving from Entertainment Tax with earmarking pattern. When it was not sufficient, recalling that the existing local tax potential was inadequate or null, the funding for the persons with disability could be provided by Central Government and the other legitimate source of funds. The regulation strategy which should be taken is to amend the Law Number 28 of 2009 and Law Numer 40 of 2007 on Corporate Social Responsibility, to establish the Law of the Persons with Disability to govern the funding.
\end{abstract}

Keywords: persons with disability, budget, state finance

\section{abstrak}

Penelitian ini berangkat dari pemikiran bahwa penyediaan anggaran bagi penyandang disabilitas merupakan hal yang sangat penting. Mengingat hal tersebut maka diperlukan pengaturan dengan baik. Penelitian ini mengangkat 
persoalan mengenai urgensi penganggaran bagi penyandang disabilitas dan strategi pendanaan serta strategi yuridis pengaturan anggaran bagi penyandang disabilitas. Penelitian ini menggunakan metode yuridis analitis yakni merupakan suatu penelitian yang dilakukan untuk menganalisis ketentuan hukum tertentu untuk kemudian digunakan dalam menjawab kebutuhan masyarakat. Dari penelitian diketahui bahwa penyediaan dana untuk penyediaan sarana dan prasarana bagi penyandang disabilitas adalah sangat urgen. Urgensi tersebut mencakup mengenai alasan-alasan sehingga perlu penyediaan dana bagi penyandang disabilitas dan penentuan macam kebutuhan yang perlu penyediaan dana. Strategi penganggaran terhadap penyandang disabilitas tergantung kepada siapa yang bertanggung jawab terhadap urusan penyandang disabilitas, dalam konteks pembagian urusan antara pemerintah pusat dan pemerintah daerah maka urusan tersebut termasuk urusan yang didesentralisasikan ke daerah. Untuk itu daerah dapat menyediakan dari Pendapatan Asli Daerah (PAD) yang berasal dari pajak hiburan dengan pola earmarking. Apabila hal tersebut belum mencukupi mengingat potensi pajak daerah yang tidak ada atau tidak memadai, maka untuk pendanaan penyandang disabilitas dapat disediakan oleh pemerintah pusat dan sumber pendanaan lain yang sah. Strategi pengaturan yang sebaiknya dilakukan adalah dengan mengamandemen Undang-Undang Nomor 28 Tahun 2009, membentuk Undang-Undang tentang Penyandang Disabilitas yang didalamnya mengatur mengenai pendanaan dan dalam menghimpun dana dari sumber lain juga dapat dilakukan dengan mengatur di dalam Undang-Undang tentang Perseroan Terbatas untuk mengamandemen ketentuan mengenai CSR.

Kata Kunci: penyandang disabilitas, anggaran, keuangan negara

\section{A. Pendahuluan}

Indonesia adalah negara hukum. Menurut Franz Magnis Suseno paham negara hukum berdasarkan keyakinan bahwa kekusaan negara harus dijalankan atas dasar hukum yang baik dan adil. ${ }^{1}$ Jadi ada dua unsur dalam paham negara hukum: pertama bahwa hubungan antara yang memerintah dan yang diperintah tidak berdasarkan kekuasaan, melainkan berdasarkan suatu norma objektif yang juga mengikat pihak yang memerintah, dan kedua bahwa norma objektif itu hukum, memenuhi syarat bukan hanya secara formal, melainkan dapat dipertahankan berhadapan dengan idea hukum. Hukum menjadi landasan segenap tindakan negara, dan hukum itu sendiri harus baik dan adil. Baik karena sesuai dengan apa yang diharapkan

1 Franz Magnis, Etika Politik, Prinsip-Prinsip Dasar Kenegaraan Modern, (Jakarta: Gramedia, 1991), hlm. 295. 
masyarakat, dari hukum, dan adil karena maksud dasar segenap hukum adalah keadilan. Ciri-ciri utama dari sebuah negara hukum menurut ilmu politik adalah : ${ }^{2}$

1. kekuasaannya dijalankan sesuai dengan hukum positif yang berlaku;

2. kegiatan negara berada di bawah kontrol kekuasaan kehakiman yang efektif;

3. berdasarkan sebuah undang-undang dasar yang menjamin hak-hak asasi manusia; dan

4. menurut pembagian kekuasaan.

Dari ciri-ciri tersebut di atas nampak salah satu cirinya adalah bahwa konstitusi negara menjamin hak-hak asasi manusia. Di dalam konstitusi Republik Indonesia telah diatur mengenai hak asasi manusia. Secara konstitusional, Indonesia di dalam Pasal 34 ayat (1) Undang-Undang Dasar Negara Republik Indonesia Tahun 1945 menentukan bahwa fakir miskin dan anak-anak yang terlantar dipelihara oleh negara. Selanjutnya pada ayat (2) ditentukan bahwa negara mengembangkan sistem jaminan sosial bagi seluruh rakyat dan memberdayakan masyarakat yang lemah dan tidak mampu sesuai dengan martabat kemanusiaan. Hal tersebut sejalan dengan Konvensi Internasional Hak-Hak Penyandang Disabilitas dan Protokol Opsional Terhadap Konvensi (Resolusi PBB No 61/1061 tanggal 13 Desember 2006) ${ }^{3}$ dan telah disahkan sebagai Undang-Undang Nomor 19 Tahun 2011 tentang Pengesahan Convention On the Rights of Persons with Disabilities (Konvensi Mengenai Hak-hak Penyandang Disabilitas) yang menyatakan bahwa tujuan konvensi ini adalah untuk memajukan, melindungi dan menjamin penikmatan secara penuh dan setara semua hakhak asasi manusia dan kebebasan fundamental oleh semua penyandang disabilitas, dan untuk meningkatkan penghormatan atas martabat yang melekat pada mereka. ${ }^{4}$ Berkaitan dengan hak ekonomi, sosial dan budaya, ${ }^{5}$

\footnotetext{
${ }^{2}$ ibid, hlm. 298.

${ }^{3}$ Sejarah panjang perlakuan terhadap penyandang disabilitas sampai pada lahirnya Konvensi Internasional tentang Hak-Hak Penyandang Disabilitas sudah menjadi fokus perhatian PBB (United Nations) dan badan/organisasi internasional lainnya. pada tahun 1983 sampai dengan 1992, Komisi PBB menunjuk 2 (dua) orang Special Rapporteurs yaitu: Leandro Despouy dan Erica-Irene Daes untuk memeriksa permasalahan terkait dengan penyandang disabilitas. Dan berdasarkan hasil laporannya ditemukan adanya diskriminasi terhadap penyandang disabilitas dalam hal voting, pekerjaan, perumahan, pelayanan kesehatan, pelayanan publik, pendidikan, trasnportasi, komunikasi, rekreasi dan kesempatan untuk berpartisipasi dalam politik. Arlene S. Kanter, the Development of Disability Rights Under International Law (From Charity to Human Rights). (New York: Routledge, 2015), hlm. 29.

${ }^{4}$ Art. 1 CRPD "Purpose" The purpose of the present Convention is to promote, protect and ensure the full and equal enjoyment of all human rights and fundamental freedoms by all persons with disabilities, and to promote respect for their inherent dignity.
} 
setiap negara pihak berkewajiban untuk mengambil langkah-langkah dengan semaksimal mungkin menggunakan sumber-sumber daya yang tersedia serta dalam kerangka kerja sama internasional ketika diperlukan dengan tujuan untuk mencapai realisasi penuh hak-hak tersebut secara progresif tanpa prasangka terhadap kewajiban-kewajiban yang tercantum dalam Konvensi ini yang harus segera diterapkan berdasarkan hukum internasional.

Pasal 5 Rancangan Undang-Undang Penyandang Disabilitas tertanggal 19 September 2014 mengatur bahwa penyandang disabilitas memiliki hak dan kesempatan yang sama dalam segala aspek kehidupan dan penghidupan, diantaranya : Hak hidup, terbebas dari stigma negatif, privasi, keadilan dan perlindungan hukum, pendidikan, pekerjaan, kesehatan, politik, keagamaan, keolahragaan, kebudayaan dan kepariwisataan, kesejahteraan sosial, aksesibilitas, pelayanan publik, kebencanaan, habilitasi dan rehabilitasi, konsesi, pendataan, hidup secara mandiri dan dilibatkan dalam masyarajat, berekspresi, berkomunikasi, dan memperoleh informasi, dan berpindah tempat dan kewarganegaraan. Selain itu, terhadap perempuan dan anak penyandang disabilitas mendapatkan perlindungan khusus.

Pasal 26 RUU Penyandang Disabilitas menyatakan bahwa Pemerintah Pusat dan Pemerintah Daerah wajib melakukan perencanaan, penghormatan, perlindungan dan pemenuhan hak Penyandang Disabilitas sehingga dengan demikian perlu adanya pembentukan mekanisme koordinasi baik di di tingkat nasional, provinsi maupun kabupaten/kota yang memiliki kewenangan untuk mewujudkan penggunaan anggaran dalam pelaksanaan penghormatan, perlindungan, dan pemenuhan hak-hak penyandang disabilitas berjalan dengan efisien (doeltreffenheid). Pembelaan dengan melakukan sikap keberpihakan terhadap mereka yang lemah, termasuk melalui penyediaan berbagai instrumen pemenuhan kebutuhan bagi penyandang disabilitas dan untuk pemberdayaan. Untuk memenuhi hal ini dapat dilakukan dengan menyediakan anggaran tersendiri melalui APBN/ APBD.

Berdasarkan uraian pada bagian latar belakang tersebut di muka, maka penelitian ini dilakukan dengan memfokuskan pada permasalahanpermasalahan 1) Apa urgensi penyediaan dana bagi penyandang disabilitas?; dan 2) Bagaimana strategi pengaturan pendanaan bagi penyandang disabilitas?

Penelitian ini bersifat yuridis analitis, yakni merupakan suatu penelitian yang dilakukan untuk menganalisis ketentuan hukum tertentu untuk kemudian digunakan dalam menjawab kebutuhan masyarakat. Dalam

\footnotetext{
${ }^{5}$ Indonesia telah meratifikasi International Covenant On Economic, Social and Culural Rights (Konvensi Internasional tentang Hak-Hak Ekonomi, Sosial dan Budaya) melalui Undang-Undang Nomor 11 Tahun 2005.
} 
hal ini dari sisi lingkup hukumnya merupakan penelitian untuk mengaji secara yuridis isi ketentuan hukum positif dalam Undang-Undang tentang Keuangan Negara dan Undang-Undang tentang Pajak Daerah dan Retribusi Daerah dihubungkan dengan anggaran disabilitas dalam keuangan negara, sekaligus mencari alternatif pemecahan permasalahan yang terkait didalamnya. ${ }^{6}$ Kajian ini dilakukan dengan menggunakan pendekatan Undang-Undang. ${ }^{7}$

\section{B. Pembahasan}

\section{Urgensi/Argumentasi Penganggaran bagi Penyandang Disabilitas}

\section{a. Urgensi Penyediaan Dana bagi Penyandang Disabilitas}

Labelisasi sosial bagi penyandang disabilitas memang tidak jarang kita lihat. Mereka dianggap orang tidak normal, cacat, dan layak untuk mendapatkan perlakuan yang tidak normal pula. Padahal sebenarnya bisa jadi keterbatasan tertentu yang dimiliki seseorang itu akan ditutup dengan kelebihan dalam soal yang lain. Ukuran normal dan tidak normal menjadi sesuatu yang kadang kala relatif, bahkan tidak jelas. Sering kali hanya yang fisik biologis dari ketidaklengkapan organ tubuh. Sebaliknya mereka yang secara fisik-biologis lengkap, dengan penglihatan lengkap, pendengaran lengkap, tangan dan jari yang lengkap, kaki juga lengkap, dianggap sebagai orang normal meski ada kemungkinan memunyai kecacatan moral, mentalitasnya lemah, mudah bersikap egois, tidak adil, cenderung mau memperbudak orang lain, menyalahgunakan kekuasaan, dan sikap perilaku negatif yang lainya, tetap saja dianggap sebagai seorang yang normal. Dalam konteks inilah lalu menjadi pertanyaan benarkah ukuran di dalam memberikan penilaian terhadap orang lain sebagai tidak normal atau cacat tersebut sudah tepat? Ataukah sebenarnya didalamnya masih tersisa adanya parameteritas penilaian subjektif yang menyebabkan orang tidak bisa memandang secara jernih dan bersikap secara bijak. Mengingat fenomena yang seperti itulah maka menarik diskursus yang berkembang yang memberikan alternatif penyebutan sebagai different abilities atau yang diterjemahkan ke dalam bahasa Indonesia ke dalam singkatan disabilitas.

Sejumlah hal dapat dijadikan alasan yang melandasi penyediaan dana bagi penyandang disabilitas:

1) kemanusiaan;

2) keadilan;

3) persamaan;

\footnotetext{
${ }^{6}$ F.Sugeng Istanto, Penelitian Hukum, (Yogyakarta: CV. Ganda, 2007), hlm. 46.

7 Peter Mahmud Marzuki, Penelitian Hukum, Cetakan Ketiga, (Kencana Prenada Media Group, 2007), hlm. 9.
} 
Dengan mendasarkan paham kesejahteraan umum sebagai keseluruhan syarat-syarat kehidupan sosial yang diperlukan masyarakat agar dapat sejahtera sekaligus pendapat para ahli ilmu negara maka Franz Magnis Suseno merumuskan adanya tiga tugas utama dari negara, yakni memberikan perlindungan kepada penduduk dalam wilayah tertentu, memberikan dukungan atau memberikan pelayanan secara langsung, dan menjadi wasit yang tidak memihak antara pihak-pihak yang berkonflik dalam masyarakat serta menyediakan suatu sistem peradilan yang menjamin keadilan dasar dalam hubungan sosial masyarakat. ${ }^{8}$

Konsep negara kesejahteraan tidak hanya mencakup deskripsi mengenai sebuah cara pengorganisasian kesejahteraan (welfare) atau pelayanan sosial (social services). Melainkan juga sebuah konsep normatif atau sistem pendekatan ideal yang menekankan bahwa setiap orang harus memperoleh pelayanan sosial sebagai haknya. ${ }^{9}$ Oleh karena itu, meskipun menekankan pentingnya peran negara dalam pelayanan sosial, negara kesejahteraan pada hakikatnya bukan merupakan bentuk dominasi negara, tetapi wujud dari adanya kesadaran warga negara atas hak-hak yang dimilikinya sesuai dengan prinsip-prinsip demokrasi. Negara diberi mandat untuk melaksanakan kewajibannya dalam memenuhi hak-hak warga negara.

Hak-hak warga negara di sini tentu saja salah satu yang berhubungan dengan kehidupannya setiap hari adalah hak untuk memenuhi kebahagiaan dan kesejahteraan hidupnya. Maka negara kesejahteraan memunyai tanggung jawab untuk senantiasa memperhatikan kebahagiaan dan kesejahteraan mereka. Ide dasar negara kesejahteraan dimulai dari abad ke18 yaitu di promosikan oleh Jeremy Bentham (1748 - 1832) bahwa pemerintah memiliki tanggung jawab untuk menjamin the greatest happiness (atau welfare) of the greatest number of their citizens. Bentham menggunakan istilah utility (kegunaan) untuk menjelaskan konsep kebahagiaan atau kesejahteraan. Berdasarkan prinsip utilitarianisme yang dikembangkan, sesuatu dapat menimbulkan kebahagiaan ekstra adalah sesuatu yang baik. Sebaliknya, sesuatu yang menimbulkan sakit adalah buruk. Menurutnya aksi-aksi pemerintah harus selalu diarahkan untuk meningkatkan kebahagiaan sebanyak mungkin orang. ${ }^{10}$

\section{b. Pemanfaatan Dana bagi Penyandang Disabilitas}

Hal penting bagi Penyandang disabilitas, Pertama adalah untuk pemberdayaan kemampuan, yang kedua adalah untuk pemenuhan kebutuhan

\footnotetext{
${ }^{8}$ Ibid, hlm. 316-317.

${ }^{9}$ Edi Suharto, Kebijakan Sosial Sebagai Kebijakan Publik, (Bandung: Alfabeta, 2011), hlm. 58.

${ }^{10}$ Ibid, hlm. 58-59.
} 
hidup. Terdapat beberapa permasalahan terkait dengan alokasi anggaran bagi penyandang disabilitas (Konsorsium Penyandang Disabilitas, 2010) diantaranya: Belum tersedianya pusat rehabilitasi yang menyelenggarakan program rehabilitasi dan habilitasi secara komprehensif (aspek sosial, kesehatan, ekonomi, pendidikan) di setiap provinsi. Rehabilitasi masih selalu dilihat secara medik, sehingga rahabilitasi yang dilakukan sebatas medis. Rehabilitasi sosial sudah dilakukan oleh Kementerian Sosial Republik Indonesia (Kemensos RI) tetapi belum sesuai kebutuhan penyandang disabilitas. Rehabilitasi vokasional yang dilakukan selama ini tidak dijalankan secara serius. Rehabilitasi vokasional dilakukan sebatas pelatihan kerja. Sebenarnya rehabilitasi vokasional juga mencakup vokasional terapi, kemudian sampai pada penempatan kerja, perlindungan terhadap produk dan pemasarannya. Peraturan mengenai pelaksanaan program CSR (Corporate Social Responsibility) belum mengatur penggunaan dana CSR bagi program pengembangan dan pemenuhan hak-hak penyandang disabilitas, termasuk habilitasi dan rehabilitasi dan kurangnya sensifitas dari sektor publik dan swasta untuk pengembangan dan pemberdayaan komunitas penyandang penyandang disabilitas dalam hal kesejahteraan sosial. Ketersediaan alat bantu hanya diberikan kepada kepada pemegang ASKES. Produksi alat bantu (kursi roda, tongkat tuna netra, prostetik, orstetik, alat bantu dengar, dan lain-lain) di Indonesia belum dapat memenuhi kebutuhan para penyandang disabilitas. Penyandang diabilitas masih mengalami kesulitan dalam mengakses modal yang diperlukan dalam mengembangkan atau memulai usaha mandiri karena ketiadaan jaminan dan kurangnya kepercayaan atas keberlangsungan usaha yang dilakukan oleh penyandang diabilitas.

Berdasarkan uraian tersebut di atas, diperlukan adanya pergantian konsep bantuan sosial, karena mindshet bantuan sosial lebih cenderung pada human charity (alasan kemanusiaan). Perlu diketahui bahwa penyandang disabilitas juga memiliki kemampuan dan keahlian yang patut diberikan apresiasi melalui program pemberdayaan di semua aspek dan tidak berdasarkan pada aspek kemiskinan.

Menurut Friedmann, pemberdayaan harus dimulai dari rumah tangga. ${ }^{11}$ Pemberdayaan rumah tangga adalah pemberdayaan yang mencakup aspek sosial, politik, dan psikologis. Yang dimaksud dengan pemberdayaan sosial adalah usaha bagaimana rumah tangga lemah memperoleh akses informasi, akses pengetahuan dan keterampilan, akses untuk berpartisipasi dalam organisasi sosial, dan akses ke sumber-sumber keuangan. Pada prinsipnya adalah bahwa pemberdayaan adalah penguatan masyarakat untuk

${ }^{11}$ Friedmann, Empowerment: The Politics of Alternative Development, (Cambridge Mass: Blackwell Publisher, 1992). 
dapat berpartisipasi dalam proses pengambilan keputusan yang mempengaruhi masa depannya, penguatan masyarakat untuk dapat memperoleh faktor-faktor produksi, dan penguatan masyarakat untuk dapat menentukan pilihan masa depannya.

Pemberdayaan masyarakat merupakan sebuah konsep pembangunan ekonomi yang merangkum nilai-nilai sosial. Konsep ini mencerminkan paradigma baru pembangunan, yakni yang bersifat people-centered, participatory, empowering, and sustainable. Konsep pemberdayaan juga perlu diberikan kepada para penyandang disabilitas. Konsep tersebut dapat diwujudkan melalui langkah nyata oleh pemerintah pusat, pemerintah daerah maupun pelaku usaha serta perlu adanya peran serta dari masyarakat untuk ikut serta dalam upaya pemberdayaan bagi penyandang disabilitas.

Terdapat beberapa upaya pemberdayaan yang dilakukan oleh pemerintah pusat maupun daerah yang ditujukan bagi penyandang disabilitas, diantaranya:

1) pemberian motivasi;

2) pemberian kursus dan pelatihan;

3) pemberian beasiswa;

4) perluasan lapangan kerja;

5) penempatan tenaga kerja;

6) permodalan, peralatan usaha dan fasilitas tempat usaha

7) akses kepada lembaga keuangan;

8) kemudahan dalam perizinan usaha;

9) membantu manajemen usaha;

10) pemberdayaan komunitas masyarakat;

11) pengembangan organisasi penyandang disabilitas;

12) bantuan hukum cuma-cuma; dan

13) upaya pemberdayaan lainnya.

\section{Strategi Pengaturan Pendanaan bagi Penyandang Disabilitas}

Untuk menentukan pendanaan bagi penyandang disabilitas diperlukan adanya langkah dan strategi tertentu. Untuk menentukan strategi yang memungkinkan dipakai dalam pendanaan bagi penyandang disabilitas, dilakukan analisis terhadap sejumah undang-undang yang terkait.

\section{a. Analisis terhadap Undang-Undang Nomor 17 Tahun 2003 tentang Keuangan Negara}

Pengelolaan keuangan negara telah diatur di dalam Undang-Undang Nomor 17 Tahun 2003 tentang Keuangan Negara. Pasal 3 ayat (4) dari Undang-Undang Nomor 17 Tahun 2003 tentang Keuangan Negara menentukan bahwa APBN/APBD memunyai fungsi otorisasi, perencanaan, 
pengawasan, alokasi, distribusi, dan stabilisasi. Di antara fungsi-fungsi tersebut ada fungsi alokasi dan fungsi distribusi. Fungsi alokasi mengandung arti bahwa anggaran negara harus diarahkan untuk mengurangi pengangguran dan pemborosan sumber daya, serta meningkatkan efisiensi dan efektivitas perekonomian. Fungsi distribusi mengandung arti bahwa kebijakan anggaran negara harus memperhatikan rasa keadilan dan kepatutan.

Mengingat berbagai fungsi tersebut di atas, terutama fungsi alokasi dan fungsi distribusi bila dihubungkan dengan persoalan penyandang disabilitas maka dapat dipandang perlu untuk mendapatkan perhatian. Oleh karena itu dalam penganggaran mesti menjadi perhatian untuk mendapatkan prioritas didahulukan.

\section{b. Analisis terhadap Undang-Undang Nomor 23 Tahun 2014 tentang Pemerintahan Daerah}

Indonesia sebagai negara kesatuan yang memiliki wilayah yang demikian luas mengambil strategi di dalam mengoptimalkan upaya menyejahterakan masyarakat sekaligus mengikat seluruh elemennya dengan menerapkan asas desentralisasi dan asas dekonsentrasi. Dengan sistem yang dibangun tersebut diharapkan keutuhan Negara Kesatuan Republik Indonesia terjaga sekaligus pelayanan kepada masyarakat dapat berjalan secara optimal. Untuk mewujudkan hal tersebut melalui perundang-undangan telah dibentuk Undang-Undang Nomor 23 Tahun 2014 tentang Pemerintahan Daerah. Undang-undang ini mencabut Undang-Undang Nomor 32 Tahun 2004 tentang Pemerintahan Daerah.

Pemberian otonomi yang seluas-luasnya kepada daerah diarahkan untuk mempercepat terwujudnya kesejahteraan masyarakat melalui peningkatan pelayanan, pemberdayaan, dan peran serta masyarakat. Di samping itu melalui otonomi luas, dalam lingkungan strategis globalisasi, daerah diharapkan mampu meningkatkan daya saing dengan memperhatikan prinsip demokrasi, pemerataan, keadilan, keistimewaan dan kekhususan serta potensi dan keanekaragaman daerah dalam sistem Negara Kesatuan Republik Indonesia.

Pemberian otonomi yang seluas-seluasnya kepada daerah dilaksanakan berdasarkan prinsip negara kesatuan. Dalam negara kesatuan kedaulatan hanya ada pada pemerintahan negara atau pemerintahan nasional dan tidak ada kedaulatan pada daerah. Oleh karena itu, seluas apa pun otonomi yang diberikan kepada daerah, tanggung jawab akhir penyelenggaraan pemerintahan daerah akan tetap ada di tangan pemerintah pusat. Untuk itu pemerintahan daerah pada negara kesatuan merupakan satu kesatuan dengan pemerintahan nasional. Sejalan dengan itu, kebijakan yang dibuat dan dilaksanakan oleh daerah merupakan bagian integral dari 
kebijakan nasional. Pembedanya adalah terletak pada bagaimana memanfaatkan kearifan, potensi, inovasi, daya saing, dan kreativitas daerah untuk mencapai tujuan nasional tersebut di tingkat lokal yang pada gilirannya akan mendukung pencapaian tujuan nasional secara keseluruhan.

Dalam pelaksanaan pemerintahan ada pembagian urusan antara Pemerintah pusat dengan pemerintah daerah. ${ }^{12}$ Secara umum ada urusan absolut yang hanya dilaksanakan oleh pemerintah pusat, dan ada urusan yang didesentralisasikan menjadi urusan daerah yang berupa urusan wajib dan urusan pilihan. Urusan pemerintahan wajib yang berkaitan dengan pelayanan dasar meliputi, pendidikan, kesehatan, pekerjaan umum dan penataan ruang, perumahan rakyat dan kawasan permukiman, ketenteraman, ketertiban umum, dan perlindungan masyarakat, dan sosial, sedangkan urusan pemerintahan wajib yang tidak berkaitan dengan pelayanan dasar meliputi, tenaga kerja, pemberdayaan perempuan dan perlindungan anak, pangan, pertanahan, lingkungan hidup, adminitsrasi kependudukan dan pencatatan sipil, pemberdayaan masyarakat desa, pengendalian penduduk dan keluarga berencana, perhubungan, komunikasi dan informatika, koperasi, usaha kecil, dan menengah, penanaman modal, kepemudaan dan olahraga, statistik, persandian, kebudayaan, perpustakaan dan kearsipan. Urusan pilihan pemerintahan meliputi, kelautan dan perikanan, pariwisata, pertanian, kehutanan, energi dan sumber daya mineral, perdagangan, perindustrian dan transmigrasi.

Di dalam Pasal 21 dari Undang-Undang tersebut ditentukan bahwa dalam menyelenggarakan otonomi, daerah memunyai hak:

1) mengatur dan mengurus sendiri urusan pemerintahannya;

2) memilih pimpinan daerah;

3) mengelola aparatur daerah;

4) mengelola kekayaan daerah;

5) memungut pajak daerah dan retribusi daerah;

6) mendapatkan bagi hasil dari pengelolaan sumber daya alam dan sumber daya lainnya yang berada di daerah;

7) mendapatkan sumber-sumber pendapatan lain yang sah; dan

8) mendapatkan hak lainnya yang diatur dalam peraturan perundangundangan.

Hak-hak sebagaimana dimaksud di atas mencerminkan adanya otonomi dan kemandirian daerah. Daerah diberikan hak yang begitu banyak, dari mengatur dan mengurus sendiri urusan pemerintahannya sendiri,

\footnotetext{
${ }^{12}$ Urusan pemerintahan terdiri atas urusan pemerintahan absolut, konkuren dan pemerintahan umum. Urusan pemerintahan yang diserahkan ke daerah yang menjadi dasar pelaksanaan otonomi daerah adalah urusan pemerintahan konkuren yang terbagi atas urusan pemerintahan wajib dan urusan pemerintahan pilihan. (vide : Undang-Undang Nomor 23 Tahun 2014 tentang Pemerintahan Daerah).
} 
mengelola kekayaan, bahkan termasuk untuk mendapatkan sumber-sumber pemasukan daerah. Hal ini menunjukkan bahwa daerah sebenarnya memunyai hak untuk menyelenggarakan pemerintahan sendiri, sehingga tidak lagi tergantung dan sangat dipengaruhi oleh pihak luar. Tentu saja kemandirian dan otonomi tersebut dalam bingkai Negara Kesatuan Republik Indonesia. Untuk penyelenggaraan urusan pemerintah pusat yang dilaksanakan di daerah sebagai konsekuensi diterapkannya asas dekonsentrasi dan asas tugas pembantuan, maka dananya masih menjadi tanggung jawab pemerintah pusat. Dengan demikian dalam pelaksanaan asas dekonsentrasi dan asas tugas pembantuan, daerah tidak hanya dibebani kewajiban tambahan dari pemerintah (pusat) begitu saja, melainkan juga disertai dengan dukungan pendanaan yang dapat bersumber dari Anggaran Pendapatan dan Belanja Negara.

Dalam pembagian urusan antara pemerintah (pusat) dengan pemerintah daerah, didalamnya ada pemberian urusan pemerintah kepada daerah. Hal seperti itu perlu dukungan kepada daerah, antara lain soal keuangan sehingga menjadi jelas hubungan keuangan antara keduanya agar dapat melaksanakan urusan tersebut dengan baik.

\section{c. Analisis terhadap Undang-Undang Nomor 33 Tahun 2004 tentang Perimbangan Keuangan Antara Pemerintah Pusat dan Pemerintahan Daerah \\ 1) Urgensi Desentralisasi Fiskal dari Pusat ke Daerah}

Pembaruan sistem keuangan negara dan daerah memiliki beberapa implikasi penting dalam pengelolaan keuangan negara dan daerah. Salah satunya komitmen penguatan kapasitas fiskal daerah sejalan dengan otonomi daerah. Pengaturan secara lebih tegas transfer of authority fiskal ke ruang pemerintah lokal telah dibingkai dalam sistem perimbangan keuangan dalam Undang-Undang Nomor 33 Tahun 2004 yang dianggap menyempurnakan Undang-Undang Nomor 25 Tahun 1999.

Dalam upaya pemberdayaan pemerintah daerah, maka perspektif perubahan yang diinginkan dalam pengelolaan keuangan daerah dan anggaran daerah adalah sebagai berikut: ${ }^{13}$

a) pengelolaan keuangan daerah harus bertumpu pada kepentingan publik (public oriented);

b) kejelasan tentang misi pengelolaan keuangan daerah pada umumnya dan anggaran daerah pada khususnya;

c) desentralisasi pengelolaan keuangan dan kejelasan peran para partisipan yang terkait dalam pegelolaan anggaran, seperti DPRD, Kepala Daerah, Sekretaris Daerah, dan Satuan Kerja Perangkat daerah lainnya;

${ }^{13}$ Ibid. 
d) kerangka hukum dan administrasi bagi pembiayaan, investasi, dan pengelolaan uang daerah berdasarkan kaidah mekanisme pasar, value for money, transparansi dan akuntabilitas;

e) kejelasan tentang kedudukan keuangan DPRD, Kepala Dinas, dan PNS daerah, baik rasio maupun dasar pertimbangannya;

f) ketentuan tentang bentuk dan struktur anggaran, anggaran kinerja, dan anggaran multitahunan;

g) prinsip pengadaan dan pengelolaan barang daerah yang lebih profesional;

h) prinsip akuntansi pemerintah daerah, laporan keuangan, peran DPRD, dan akuntan publik dalam pengawasan, pemberian opini dan rating kinerja anggaran, dan transparansi informasi anggaran kepada publik;

i) aspek pembinaan dan pengawasan yang meliputi batasan pembinaan, peran asosiasi, dan peran anggota masyarakat guna pengembangan profesionalisme aparat pemerintah daerah; dan

j) pengembangan sistem informasi keuangan daerah untuk menyediakan informasi anggaran yang akurat dan pengembangan komitmen pemerintah daerah terhadap penyebarluasan informasi sehingga memudahkan pelaporan dan pengendalian, serta memudahkan mendapatkan informasi.

Secara garis besar perimbangan keuangan pusat dilakukan dengan beberapa tujuan. ${ }^{14}$ Pertama, pembelanjaan daerah untuk melayani masyarakatnya. Kedua, mendorong upaya oleh pemerintah daerah untuk menjalankan program-program pembangunan yang disesuaikan dengan kebijaksanaan nasional. Ketiga, merangsang perumbuhan ekonomi daerah, baik untuk membantu pertumbuhan maupun untuk mengurangi ketimpangan antar wilayah. Keempat, mengendalikan pengeluaran regional, kelima, memantapkan standar pelayanan atau pembangunan yang lebih adil. Keenam, mengembangkan wilayah-wilayah yang kapasitas fiskalnya rendah, dan ketujuh adalah untuk membantu wilayah dalam mengatasi keadaankeadaan darurat.

Mengenai arah kebijakan perimbangan keuangan antara pusat dan daerah dapat dilihat dari pengertian perimbangan keuangan antara pusat dan daerah sebagaimana telah diatur dalam Pasal 1 angka 3 UU No. 33 Tahun 2004 yang menyatakan suatu sistem pembagian keuangan yang adil, proporsional, demokratis, transparan, dan efisien dalam rangka pendanaan penyelenggaraan desentralisasi, dengan mempertimbangkan potensi, kondisi, dan kebutuhan daerah, serta besaran pendanaan penyelenggaraan dekonsentrasi dan tugas pembantuan. Mengacu definisi tersebut memberikan pengertian bahwa alokasi anggaran oleh pemerintah pusat kepada daerah

${ }^{14}$ I Putu Wijaya dkk, Kebijakan Pengaturan Perimbangan Keuangan dalam Konsepsi dan Perspektif Keadilan, Jurnal Hukum Keadilan, Bali, 2007. 
merupakan wujud tanggung jawab pemerintah kepada rakyat di daerah yang dilaksanakan melalui berbagai bentuk pelayanan publik yang dilaksanakan oleh pemerintah daerah sebagai ujung tombak pelayanan terhadap masyarakat.

\section{d. Analisis terhadap Undang-Undang Nomor 28 Tahun 2009 tentang Pajak Daerah dan Retribusi Daerah 1) Jenis Pajak dan Objek Pajak}

Undang-Undang Nomor 28 Tahun 2009 merupakan pengganti Undang-Undang Nomor 18 Tahun 1997 sebagaimana telah diubah dengan Undang-Undang Nomor 34 Tahun 1989 tentang Pemerintahan Daerah. Pajak dan retribusi daerah adalah dua sumber penerimaan daerah yang telah dipungut di Indonesia sejak awal kemerdekaan Indonesia. Sumber penerimaan ini terus dipertahankan sampai dengan era otonomi daerah dewasa ini. ${ }^{15}$ Dalam perkembanganya mengalami perubahan yang dinamis.

Sebelum lahir Undang-Undang Nomor 18 Tahun 1997 Tentang Pajak Daerah dan Retribusi Daerah yang didasarkan pada Undang-undang Nomor 11 Drt. Tahun 1957 tentang Peraturan Umum Pajak Daerah dan Undangundang Nomor 12 Drt. Tahun 1957 tentang Peraturan Umum Retribusi Daerah jenisnya sangat banyak. Hal tersebut menyulitkan di dalam pemungutan. Bahkan tidak sedikit jenis pajak yang sebenarnya menurut ketentuan dapat dikenakan akan tetapi di dalam praktik sulit untuk dikenakan. Melihat kenyataan tersebut maka pemerintah bersama DPR dengan menerbitkan Undang-Undang Nomor 18 Tahun 1997 kemudian memangkas jenis pajak tersebut menjadi sembilan jenis saja, yakni 3 jenis pajak daerah tingkat I dan 6 jenis pajak daerah tingkat II.

Model yang dipakai di dalam undang-undang tersebut adalah maximum list atau clossed list, artinya pemerintah provinsi daerah tingkat I hanya dapat memungut tiga jenis pajak itu saja, demikian pula pemerintah Kabupaten/Kota Daerah tingkat II juga hanya dapat memungut 6 jenis pajak itu, selebihnya tidak boleh dipungut lagi. Hal tersebut memaksa daerah untuk sangat membatasi peluangnya dalam memungut pajak. Padahal kondisi masing-masing daerah sangat berbeda-beda. Oleh karena itu pada tahun 2000 dilakukan perubahan dengan membuat kebijakan yang lebih terbuka berdasarkan Undang-Undang Nomor 34 Tahun 2000 tentang Perubahan Atas Undang-Undang Nomor 18 Tahun 1997 tentang Pajak Daerah dan Retribusi Daerah, yakni jenis pajaknya ditentukan bertambah menjadi sebanyak 4 jenis untuk pajak provinsi dan 7 jenis untuk pajak kabupaten/kota.

${ }^{15}$ Marihot Pahala Siahaan, Pajak Daerah dan Retribusi Daerah, (Jakarta: PT. Raja Grafindo Persada, 2010), hlm. 11. 
Dari jenis pajak yang tersebut di atas sebenarnya tidak ada yang baru, karena pajak pengambilan dan pemanfaatan air bawah tanah dan air permukaan yang sebelumnya merupakan pajak daerah tingkat II dipindahkan menjadi pajak provinsi, sementara untuk pajak daerah tingkat II ada pemecahan antara pajak hotel dan pajak restoran. Khusus untuk pemerintah kabupaten/kota boleh memungut jenis pajak lainya (open list) dengan syaratsyarat tertentu, yakni ditetapkan berdasarkan peraturan daerah dengan kriteria :

a) bersifat pajak dan bukan retribusi;

b) objek pajak terletak atau terdapat di wilayah daerah Kabupaten/Kota yang bersangkutan dan memunyai mobilitas yang cukup rendah serta hanya melayani masyarakat di wilayah Daerah Kabupaten/Kota yang bersangkutan;

c) objek dan dasar pengenaan pajak tidak bertentangan dengan kepentingan umum;

d) objek pajak bukan merupakan objek pajak propinsi dan/atau objek pajak pusat;

e) potensinya memadai;

f) tidak memberikan dampak ekonomi yang negatif;

g) memperhatikan aspek keadilan dan kemampuan masyarakat; dan

h) menjaga kelestarian lingkungan (Pasal 2 ayat (4) Undang-Undang Nomor 34 Tahun 2000).

Setelah keluarnya Undang-Undang Nomor 28 Tahun 2009, maka jenis pajaknya diubah. Untuk Pajak Provinsi, yang sebelumnya disebut pajak daerah tingkat I ditambah menjadi 5 jenis, sementara untuk pajak kabupaten/kota yang sebelumnya disebut dengan pajak daerah tingkat II ada 11 jenis.

a) Jenis pajak provinsi terdiri atas:

(1) pajak kendaraan bermotor;

(2) bea balik nama kendaraan bermotor;

(3) pajak bahan bakar kendaraan bermotor;

(4) pajak air permukaan; dan

(5) pajak rokok.

b) Jenis pajak kabupaten/kota terdiri atas:

(1) pajak hotel;

(2) pajak restoran;

(3) pajak hiburan;

(4) pajak reklame;

(5) pajak penerangan jalan;

(6) pajak mineral bukan logam dan batuan;

(7) pajak parkir;

(8) pajak air tanah; 
(9) pajak sarang burung walet;

(10) pajak bumi dan bangunan perdesaan dan perkotaan; dan

(11) bea perolehan hak atas tanah dan bangunan.

Model yang dipakai dalam Undang-Undang Nomor 28 Tahun 2009 kembali ke maximum list/ clossed list. Dengan penambahan tersebut maka pemerintah provinsi dapat memungut pajak rokok, yang merupakan jenis pajak baru. pajak rokok berbeda dengan cukai, dan tidak menghapuskan pengenaan cukai., atau dengan kata lain bahwa cukai terhadap rokok masih tetap dikenakan oleh pemerintah pusat.

Pemerintah kabupaten/kota dengan undang-undang yang baru ini dapat memungut pajak terbatas pada sebelas jenis pajak yang ada. Dari kesebelas jenis pajak yang dapat dipungut oleh pemerintah kabupaten/kota tersebut dua diantaranya merupakan jenis pajak yang sebelumnya menjadi pajak pusat. kedua jenis pajak tersebut adalah pajak bumi dan bangunan khususnya untuk perdesaan dan perkotaan, dan bea perolehan hak atas tanah dan bangunan. Pada waktu berlakunya Undang-Undang Nomor 18 Tahun 1997 sebagaimana diubah dengan Undang-Undang Nomor 34 Tahun 2000 semua Pajak Bumi dan Bangunan merupakan Pajak Pusat dan dikelola oleh Pemerintah Pusat. Dari sisi potensi dan kewenangan pemungutan pajak bagi daerah hal tersebut dapat dipandang sebagai sebuah kemajuan. Sekalipun demikian bila dibandingkan dengan sejumlah negara Asia Tenggara lainya seperti Filipina, Thailand, Malaysia kita bisa dikatakan ketinggalan. Mereka telah lama memberikan kewenangan kepada daerah untuk mengenakan pajak bumi dan bangunan sebagai property tax. Filipina memberikan kewenangan kepada daerah untuk memungut the real property tax sejak diundangkannya Local Government Act 1959, sementara Thailand memberikan kewenangan kepada daerah untuk memungut a single property based tax tahun 1999. Malaysia memberikan kewenangan kepada daerah berupa property tax sejak diundangkannya Local Government Act 1976. ${ }^{16}$ Pengalihan sebagian pajak bumi dan bangunan serta bea perolehan hak atas tanah dan bangunan menjadi pajak kabupaten/kota tentu menjadikan semakin kuat potensi pendapatan asli daerah. Hal tersebut disebabkan oleh beberapa hal:

Pertama, bahwa objek pajak bumi dan bangunan adalah bumi dan/atau bangunan. Objek pajak tersebut tidak mungkin tidak tersedia di wilayah kabupaten/kota yang bersangkutan. Hampir setiap orang memiliki dan memerlukan bumi dan/atau bangunan, maka tentu ini menjadi potensi pajak yang selalu tersedia di daerah sehingga dalam hal ini PBB memainkan peran berperan penting di bidang keuangan pemerintah daerah. Hal serupa juga berlaku bagi bea perolehan hak atas tanah dan/atau bangunan, karena Bea

${ }^{16}$ Larry Schroeder,Fiscal Decentralization in South East Asia, (Journal of Public Budgeting, Accounting \& Financial Management, Vol.15 No.3, Academic Press), 2003, hlm. 392-405. 
Perolehan Hak atas Tanah dan/atau Bangunan dikenakan terhadap perolehan hak atas tanah dan/atau bangunan.

Kedua, dasar pengenaan pajak untuk Pajak Bumi dan Bangunan adalah Nilai Jual Objek Pajak maka semakin tinggi nilai jualnya semakin tinggi pajaknya, sebaliknya semakin rendah nilai jualnya juga semakin rendah pajaknya. Dengan demikian tentu menguntungkan bagi daerah yang rerata nilai jual objek pajaknya tingi, karena akan dapat memungut pajak yang tinggi pula.

Ketiga, mobilitas objek pajaknya bisa dikatakan sangat kecil atau bahkan tidak mungkin, karena yang terjadi andai kata ada peralihan hak itu hanya soal kepemilikannya, akan tetapi objeknya yang berupa bumi dan/atau bangunan itu tetap di tempat semula. Andaikan mungkin beralih ke tempat (Kabupaten/Kota) lain itu hanya terbatas untuk bangunan. Dengan demikian bagi pemerintah Kabupaten/Kota yang bersangkutan tetap dapat memungut pajak tersebut.

Hal lain selain kedua jenis pajak tersebut di atas yang ditambahkan ke dalam pajak kabupaten/kota adalah pajak sarang burung walet. Pajak sarang burung walet pernah dikenal sebelum lahirnya Undang-Undang Nomor 18 Tahun 1997. Jenis pajak ini tidak bisa dikatakan memunyai basis objek yang merata. Hal tersebut disebabkan karena kondisi masing-masing daerah berbeda. Sebagai objek pajak dari pajak sarang burung walet adalah pengambilan atau pengusahaan sarang burung walet. Burung walet sebagai satwa secara alamiah menyukai lingkungan yang dekat dengan air sungai, laut, waduk, rawa, dan sebagainya. Kehidupan burung walet sangat erat dengan keberadaan air tersebut karena umumnya burung walet mencari makan di sekitar air tersebut. Oleh karena itu Daerah yang bisa mengenakan Pajak Sarang Burung Walet adalah daerah yang memunyai potensi berkembang dan hidupnya burung walet. Daerah Kabupaten/Kota yang tidak dilalui sungai besar, tidak terdapat waduk/bendungan, rawa, danau, tidak dekat dengan laut kemungkinan akan sulit memungut pajak sarang burung walet.

Pajak Kabupaten/Kota juga bertambah karena adanya pajak air tanah. Hal ini merupakan pengalihan hasil pecahan pajak daerah tingkat I yang sebelumnya berupa pajak pengambilan air bawah tanah dan air permukaan. Dengan Undang-Undang Nomor 28 Tahun 2009 tersebut pajak pengambilan air bawah tanah dan air permukaan yang semula merupakan pajak daerah tingkat I dipecah menjadi dua, yakni untuk pajak air permukaan menjadi pajak provinsi, sedangkan pajak air tanah dijadikan pajak kabupaten/kota. Memang pajak pengambilan air bawah tanah dan air permukaan mengalami beberapa kali perubahan penempatan, berpindah-pindah antara pajak daerah tingkat I (sekarang pajak provinsi) dengan pajak daerah tingkat II (sekarang pajak kabupaten/kota). 
Dari lima pajak provinsi dan sebelas pajak Kabupaten/Kota tersebut telah dapat diketahui masing-masing objek pajaknya. Keenambelas jenis pajak tersebut ada yang potensinya pasti ada di masing-masing daerah, seperti pajak kendaraan bermotor, bea balik nama kendaraan bermotor, pajak bumi dan bangunan, dan bea perolehan hak atas tanah dan/ atau bangunan dan pajak rokok. Ada pula jenis pajak yang potensinya hanya ada di sebagian daerah seperti pajak air permukaan, pajak hotel, pajak hiburan, pajak sarang burung walet, dan sebagainya. Oleh karena itu apabila menghendaki pengalokasian hasil pajak untuk membiayai sesuatu pengeluaran, maka tentu juga harus mempertimbangkan mengenai hal tersebut.

\section{2) Earmarking dalam Pengalokasian Hasil Pajak}

Indonesia telah menerapkan eramarking dalam bentuk revenue sharing dari pemerintah pusat ke pemerintah daerah.

Dalam Undang-Undang Nomor 28 Tahun 2009 tentang Pajak Daerah dan Retribusi Daerah diatur mengenai penggunaan anggaran yang sumber penerimaan maupun program pengeluarannya secara spesifik ditentukan peruntukannya atau yang sering dikenal sebagai earmarking. Ada tiga jenis pajak yang dalam pengalokasian hasil pungutannya diatur pengalokasiannya melalui earmarking. Ketiga jenis pajak tersebut adalah pajak kendaraan bermotor, pajak rokok, dan pajak penerangan jalan.

Di dalam Pasal ayat (5) dari Undang-Undang Nomor 28 Tahun 2009 ditentukan bahwa: "Hasil penerimaan pajak kendaraan bermotor paling sedikit $10 \%$ (sepuluh persen), termasuk yang dibagihasilkan kepada kabupaten/kota, dialokasikan untuk pembangunan dan/atau pemeliharaan jalan serta peningkatan moda dan sarana transportasi umum." Untuk earmarking pajak rokok diatur di dalam Pasal 31 Undang-Undang Nomor 28 Tahun 2009 yang menentukan: "penerimaan pajak rokok, baik bagian provinsi maupun bagian kabupaten/kota, dialokasikan paling sedikit $50 \%$ (lima puluh persen) untuk mendanai pelayanan kesehatan masyarakat dan penegakan hukum oleh aparat yang berwenang." Pengaturan terhadap earmarking pajak penerangan jalan diatur dalam Pasal 56 ayat (3) yang menentukan: "hasil penerimaan pajak penerangan jalan sebagian dialokasikan untuk penyediaan penerangan jalan."

Di dalam bidang pajak dikenal adanya dua fungsi pajak, yakni fungsi budgeter dan fungsi mengatur. Fungsi budgeter adalah bahwa pajak digunakan untuk dijadikan instrumen penerimaan negara dalam rangka membiayai pengeluaran pemerintah. Sementara fungsi mengatur (regulerend) bahwa pajak dijadikan instrumen untuk mengarahkan 
masyarakat ke hal-hal tertentu yang dikehendaki oleh pemerintah. ${ }^{17}$ Pemerintah memiliki fungsi regulasi yang digunakan untuk mengetahui tujuan-tujuan tertentu dalam rangka pengenaan pajak. Pajak memiliki peran dalam melakukan koreksi terhadap eksternalitas yang timbul dari suatu peristiwa, sebagai contoh : pengenaan pajak kendaraan bermotor untuk mengatasi pelbagai eksternalitas negatif yang ditimbulkan seperti polusi dan kerusakan jalan raya, sehingga pemerintah mengatur pertumbuhan ekonomi melalui kebijaksanaan pajak.

Dalam hal earmarking lebih membicarakan penggunaan uang pajak setelah berhasil dipungut dari masyarakat, bukan terutama soal pengaruh pemungutan pajak bagi masyarakat. Dengan demikian sebenarnya lebih bicara mengenai penerapan fungsi budgeter. Akan tetapi dalam hal tertentu penggunaan dana dari hasil pajak juga dapat mempengaruhi masyarakat. Penggunaan dana hasil pemungutan pajak hiburan untuk pendanaan bagi penyandang disabilitas, kiranya dapat memengaruhi animo dalam membayar pajak, terutama bila masyarakat tahu bahwa hasilnya digunakan untuk itu sekaligus merasakan hasilnya secara signifikan. Sehingga dengan demikian, peruntukan pajak hiburan yang dialokasikan untuk penyandang disabilitas menjadi salah satu strategi pendanaan yang jitu, mengingat tujuan yang hendak dicapai dalam pengenaan pajak tersebut sudah jelas peruntukannya. Bila didasarkan dari prinsip negera kesejahteraan (welfare state) yang mana peran negara menjadi sangat urgen dalam hal pemenuhan hak-hak dasar (grondrechten bescherming) terkhusus penyandang disabilitas melalui kebijaksanaan pajak menjadi preseden baik bagi upaya pencapaian kesejahteraan masyarakat yang saling berkesinambungan satu sama lain, mengingat pola hubungan antar manusia yang saling membutuhkan dan melengkapi satu sama lain sebagai makhluk sosial.

\section{e. Alternatif Pendanaan}

Pendanaan bagi penyandang disabilitas menjadi sesuatu yang penting untuk dipikirkan dan diputuskan. Hal ini terjadi karena penyediaan sarana dan prasarana bagi penyandang disabilitas memang sangat diperlukan. Ada sejumlah permasalahan di dalam penyediaan dana:

Pertama adalah siapa yang bertanggung jawab atas pendanaan tersebut, dalam hal ini pemerintah pusat, pemerintah Provinsi, atau pemerintah Kabupaten/kota? Kedua, dari mana sumber pendanan tersebut diperoleh dan dengan cara bagaimana dana tersebut disediakan?

Mengenai siapa yang bertanggung jawab terhadap penyediaan dana bagi pemenuhan kebutuhan penyandang disabilitas kiranya dapat didekati

${ }^{17}$ Sri Pudyatmoko, Pengantar Hukum Pajak, cetakan kelima, (Yogyakarta: Penerbit Andi, 2009), hlm. 16-17. 
dari pembagian urusan pemerintahan. Bila urusan itu menjadi kewenangan pemerintah pusat maka itu murni menjadi tanggung jawab pemerintah pusat, akan tetapi bila hal tersebut merupakan urusan yang menjadi kewenangan pemerintah daerah, maka yang mestinya bertanggung jawab adalah pemerintah daerah. Meski demikian tidak menutup kemungkinan bantuan dari pemerintah pusat, maupun pihak swasta.

Dari mana pendanaan itu diperoleh merupakan masalah yang mesti dicari jawabanya. Apabila pendanaan menjadi tanggung jawab pemerintah pusat, maka pemerintah pusat dapat mengalokasikan dana dari sumbersumber yang ada, seperti dari APBN, maupun dari sumber lain yang sah. Sumber lain yang sah misalnya dari pihak ke-3 atau dari pihak swasta baik itu di dalam pengelolaan pemerintah maupun dikelola sendiri oleh pihak ke3 seperti dengan CSR (Corporate Social Responsibility). Sebaliknya apabila pendanaan menjadi tanggung jawab pemerintah daerah maka pemerintah daerah dapat mengalokasikan dana dari sumber-sumber yang ada, seperti dari APBD, penggunaan kekayaan daerah, ataupun dari sumber-sumber lain yang sah.

Dengan cara apa dana itu dapat disediakan oleh Pemerintah Pusat, tergantung macam dananya. Apabila itu berasal dari APBN tentu dengan penyediaan langsung, akan tetapi apabila dari pihak ke-3 maka bisa dengan pembuatan kebijakan pemerintah pusat yang menentukan bahwa perusahaan dalam menyediakan CSR sebagian dialokasikan untuk pemenuhan kebutuhan penyandang disabilitas. Apabila dana tersebut berasal dari APBD maka hal tersebut dapat dialokasikan dari APBD melalui pos pengeluaran SKPD yang menangani permasalahan sosial. Sumber di APBD dapat diambilkan dari hasil penerimaan pajak maupun retribusi yang memunyai relevansi dengan persoalan sosial. Mengingat relevansi tersebut maka kiranya model earmarking dari dana yang berasal dari pajak hiburan bisa masuk. Sumber lain yang kiranya dapat menjadi alternatif adalah dari hasil penggunaan dan pemanfaatan kekayaan daerah. Hal ini disebabkan karena yang berhak atas kekayaan daerah adalah semua rakyat, baik yang disabilitas maupun kaum yang tidak disabilitas. Earmarking merupakan salah satu langkah untuk dapat mencapai efisiensi anggaran pemerintah, yaitu kebijakan pemerintah dalam menggunakan anggaran yang sumber penerimaan maupun program pengeluarannya akan secara spesifik ditentukan peruntukannya. Dalam pelaksanaannya, praktik earmarking telah berkembang pesat di berbagai negara, baik negara maju maupun berkembang. Di Kolombia, earmarking telah diberlakukan sejak tahun 1921, di mana program kebijakan earmarking ditujukan untuk meningkatkan infrastruktur di daerah (municipal). Di Australia, earmarking yang paling 
populer adalah Medicare Levy, di mana tujuan dari earmarking ini untuk membantu pembiayaan dalam pelayanan kesehatan. ${ }^{18}$

Contoh lain dari penggunaan earmarking adalah di Amerika Serikat, selain dengan transfer dana dari pusat ke daerah, sektor pendidikan dibiayai dengan property tax (di Indonesia dikenal dengan Pajak Bumi dan Bangunan) yang merupakan pajak daerah. Sedangkan di Filipina, berkaitan pajak pendidikan khusus diambilkan dari $1 \%$ pengenaan property tax (other land-base tax) yang mana hasilnya diperuntukan untuk pendidikan umum, hasil dari pajak tersebut termasuk dalam angka pendapatan yang dilaporkan sebelumnya. ${ }^{19}$ Jadi, tinggi rendahnya tarif property tax ditentukan berdasarkan besar kecilnya kebutuhan pendanaan pendidikan di daerah itu. Jika suatu daerah ingin pembangunan pendidikannya lebih baik daripada daerah lain, secara sadar, mereka harus membayar property tax lebih tinggi.

Dengan earmarking ini menurut Edy Priyono dalam konteks earmarking untuk dana pendidikan ada beberapa keuntungan. Pertama, kebijakan perpajakan daerah ada di tangan Pemda. Kedua, ada mekanisme transaksi yang jelas antara pemungut pajak dengan wajib pajak. Dalam banyak kasus, masyarakat Indonesia mau membayar besar untuk keperluan sektor publik jika mereka yakin, uang itu digunakan dengan baik. Dengan kata lain, dengan sistem ini, ada potensi memobilisasi dana lebih besar. Sistem ini juga lebih accountable. Masyarakat mudah melihat penggunaannya dengan mengaitkan antara penerimaan pajak tertentu dan anggaran pendidikan. ${ }^{20}$

Pemilihan pajak hiburan sebagai sumber dana bagi keperluan penyediaan sarana dan prasarana bagi penyandang disabilitas bukanlah sesuatu yang tanpa dasar. Pertama bahwa di dalam konteks penanganan urusan, maka urusan sosial kemasyarakatan dapat dipandang sebagai urusan pemerintah yang didesentralisasikan ke daerah. Ini memang sangat masuk akal karena yang mengetahui persis kondisi yang nyata terutama adalah pemerintah daerah. Kedua dari sisi penyediaan anggaran, kalau sebuah urusan merupakan urusan pemerintah daerah maka mestinya pemerintah daerah yang sangat bertanggung jawab untuk menyediakan dananya. Ketiga alasan relevansi, pemilihan pajak hiburan sebagai sumber dana itu karena objek dari pajak hiburan adalah penyediaan jasa berupa hiburan yang

\footnotetext{
${ }^{18}$ Direktorat Jenderal Perimbangan Keuangan, Departemen Keuangan Republik Indonesia. (http://www.djpk.kemenkeu.go.id), http://www.fiskal.depkeu.go.id/2010/m/edef-kontenview-mobile.asp?id, diunduh tanggal 12 Oktober 2015.

${ }^{19}$ Richard M. Bird and Eid Slack, International Handbook of Land and Property Taxation, Edward Elgar Publishing, Inc, (USA: Massachusetts, , 2003), hlm. 157.

20 Edy Priyono, "Earmarking" Untuk Biayai Pendidikan Daerah, dalam http://www.akademika.or.id/arsip/Earmarking untuk Biayai Pendidikan Daerah-Jumat ,2005 Maret 2004.html, diunduh 14 Oktober 2015.
} 
disajikan untuk khalayak. Oleh karena itu kalau yang dikenai pajak hiburan adalah penyediaan jasa hiburan maka jelas di situ diberikan kepada mereka yang menikmati hiburan, sementara di sisi lain masih ada warga bangsa yang kurang beruntung yakni penyandang disabilitas, maka tepatlah kalau merekapun berhak untuk mendapatkan uluran perhatian. Hal ini selaras dengan prinsip subsidiaritas yang telah diuraikan sebelumnya. Keempat, dengan menggunakan model earmarking karena hal ini menjadi salah satu model pengalokasian dana yang dikenal dalam Undang-Undang Nomor 28 Tahun 2009 tentang Pajak Daerah dan Retribusi Daerah dan diharapkan dapat efektif.

Mencermati uraian yang tertuang dalam beberapa perda tentang disabilitas tersebut nampaknya perlu menyesuaikan penganggaran yang memiliki perspektif hak-hak penyandang disabilitas yang sudah diatur dalam Convention on The Rights of Persons with Disabilities/ Konvensi Internasional Penyandang Disabilitas (CRPD). Implementasi CRPD akan bisa terwujud apabila dilakukan secara kolektif dan berkelanjutan di lintas pemangku kepentingan atau lintas sektoral serta memiliki perimbangan antara kebijakan dan penganggaran yang proporsional di tingkat pusat maupun daerah.

\section{f. Strategi Pengaturan}

Melihat realitas sebagaimana diuraikan di atas, maka yang dapat dilakukan untuk pengaturannya adalah dengan melakukan amandemen terhadap Undang-Undang tentang Pajak Daerah dan Retribusi Daearah. Amandemen tersebut terutama berkaitan dengan pemasukan kewajiban pengalokasian hasil dari pajak hiburan ke dalam penyediaan sarana dan prasarana bagi penyandang disabilitas.

Ada kemungkinan bahwa pengalokasian dana hasil pemungutan pajak hiburan tidak mencukupi untuk memenuhi kebutuhan bagi penyandang disabilitas, atau bahkan di daerah tersebut tidak ada pajak hiburan karena memang potensinya belum bisa dipungut. Terhadap hal yang seperti itu sesungguhnya masih ada alternatif lain untuk menggali sumber dana bagi penyandang disabilitas. Dana tersebut dapat berasal dari pemerintah pusat. Dana yang tersedia bagi pemerintah daerah yang berasal dari pemerintah pusat ada beberapa sumber, yakni dana bagi hasil, dana alokasi umum, dan dana alokasi khusus.

Dana Bagi Hasil dapat berupa hasil penerimaan pajak dan penerimaan sumber daya alam. Dana bagi hasil yang berasal dari penerimaan pajak kiranya agak sulit untuk diketemukan justifikasi relevansinya bila akan dialokasikan langsung kepada pengeluaran pemerintah daerah bagi penyandang disabilitas dengan pola earmarking, kecuali untuk dana bagi hasil dari pajak penghasilan. Sementara dana bagi hasil dari penerimaan 
kekayaan alam dapat dialokasikan kepada penyandang disabilitas dengan mendasarkan pada keadilan, yakni bahwa yang berhak atas kekayaan alam adalah semua warga bangsa Indonesia, termasuk penyandang disabilitas.

Dana alokasi umum merupakan dana yang berasal dari APBN yang dialokasikan dengan tujuan pemerataan kemampuan keuangan antar daerah untuk membiayai kebutuhan pengeluaran dalam rangka pelaksanaan desentralisasi. Pengunaan dana alokasi umum ini ditetapkan sepenuhnya oleh daerah. Termasuk di dalam pengertian pemerataan kemampuan keuangan daerah adalah jaminan kesinambungan penyelenggaraan pemerintahan daerah di seluruh daerah dalam rangka penyediaan pelayanan dasar kepada masyarakat, dan merupakan satu kesatuan dengan penerimaan umum Anggaran Pendapatan dan Belanja Daerah. Penggunaan Dana Alokasi Umum dan penerimaan umum lainya dalam APBD, harus tetap dalam kerangka pencapaian tujuan pemberian otonomi kepada daerah yaitu peningkatan pelayanan dan kesejahteraan masyarakat yang semakin baik, seperti di bidang kesehatan dan pendidikan. ${ }^{21}$

Pola penganggaran yang tertuang dalam beberapa peraturan tentang disabilitas hanya bersifat umum, tidak rigid dan detail. Sehingga ketika diimplementasikan tidak bisa meng-cover kebutuhan penyandang disabilitas. Pemerintah daerah perlu mengalokasikan anggaran khusus bagi penyandang disabilitas. Hal tersebut dapat dilakukan dengan berbagai cara: sumber penerimaan pendapatan daerah dari sektor pajak, misal pajak hiburan dapat dialokasikan bagi penyandang disabilitas, daerah yang memiliki sumber pendapatan dari sektor pariwisata, seperti Bali, Lombok, dapat mengalokasikan persentase keuntungan untuk pendanaan bagi disabilitas.

Besaran persentase penganggaran didasarkan pada aspek proporsionalitas dan dituangkan secara jelas di dalam peraturan perundangundangan, hal tersebut untuk memberikan kemudahan dalam implementasinya dan digunakan untuk mendukung suatu pemberdayaan bagi penyandang disabilitas, diantaranya: Program Rehablitasi idealnya tersedia di setiap Provinsi dan diselenggarakan secara menyeluruh termasuk diantaraya harus menyediakan layanan kesehatan, terapi fisik, bimbingan konseling/psikis, vokasional dan kehidupan sosial dan pendidikan, program rehabilitasi dan habilitasi harus ditujukan untuk penguatan dan pemberdayaan, Pendampingan harus dilakukan mulai dari pelatihan soft skill, tips interview, sampai pada tahap penempatan kerja, selama bekerja, perlindungan produk dan perlindungan pasar,

Mendukung sektor swasta untuk membuat tindakan-tindakan afirmasi dalam upaya pemenuhan hak-hak penyandang disabilitas melalui program-

${ }^{21}$ Ahmad Yani, Hubungan Keuangan Antara Pemerintah Pusat dan Daerah di Indonesia, (Jakarta: Penerbit PT. Raja Grafindo Persada, 2002), hlm. 10. 
program CSR, diantaranya dengan menyusun peraturan yang terkait dengan pelaksanaan Program CSR untuk pemberdayaan penyandang disabilitas dan menosialisasikannya kepada sektor publik dan swasta. Kebutuhan akan alat bantu tersebut, harus dialokasikan dalam kebijakan nasional dan dalam Anggaran Belanja Negara maupun Daerah, Pemerintah mendorong munculnya kearifan lokal terkait dengan penyediaan alat bantu dengan memanfaatkan sumber daya lokal.

Rekomendasi yang disusun secara sistematis ini diharapkan dapat memberikan masukan untuk perbaikan dan reformasi hukum dan kebijakan di masa mendatang mampu menjadi landasan hukum maupun landasan pembuatan program pembangunan dan penganggaran yang memiliki perspektif hak-hak penyandang disabilitas yang sudah diatur dalam CRPD. Implementasi CRPD akan bisa terwujud apabila dilakukan secara kolektif dan berkelanjutan di lintas pemangku kepentingan atau lintas sektoral serta memiliki perimbangan antara kebijakan dan penganggaran yang proporsional di tingkat pusat maupun daerah. Setelah CRPD diratifikasi di Indonesia, sudah saatnya semua sektor di negara ini melakukan perubahan yang sistematis dan berkesinambungan demi tercapainya kesetaraan dan kesamaan hak-hak bagi penyandang disabilitas.

\section{g. Besar Dana yang Dialokasikan untuk Mendanai Penyandang Disabilitas}

Ukuran untuk menentukan besaran dari perhatian terhadap sesuatu hal antara lain dapat dilihat dari porsi penganggaran. Sebagaimana diketahui sebenarnya dalam konteks pajak daerah, pajak hiburan pada umumnya memegang peranan yang tidak terlalu besar (signifikan). Akan tetapi bila dari jumlah yang tidak terlalu besar tersebut dapat disisihkan sebagian untuk memberikan perhatian terhadap penyandang disabilitas, maka hal tersebut tentu menjadi hal yang sangat menarik. Sebagai gambaran, dari jenis pajak yang telah dialokasikan secara langsung (earmarking) tarifnya bervariasi. Hasil dari pajak kendaraan bermotor menurut undang-undang paling sedikit dialokasikan untuk perbaikan jalan sebesar $10 \%$, hasil dari pajak rokok paling sedikit 50\% yang dialokasikan secara langsung, sementara untuk pajak penerangan jalan tidak dipertegas tarifnya. Dalam undang-undang hanya dikatakan bahwa sebagian dari hasil pajak penerangan jalan digunakan untuk menyediakan penerangan umum.

Alternatif penentuan besaran pengalokasian dana memang dapat berkaca dari tiga jenis pajak yang sudah terlebih dahulu dialokasikan dengan pola earmarking. Dari ketiga jenis pajak tersebut tidak ada pola yang sama di dalam penentuan besaran alokasi dana. Oleh karena itu, kiranya kebutuhan bagi penyandang disabilitas dan kemampuan keuangan pemerintah pusat dan pemerintah daerah menjadi referensi di dalam 
penentuan besaran dana. Fleksibilitas penentuan besaran alokasi dana juga dapat diterapkan dengan belajar dari pengalokasian dana pendidikan di Amerika Serikat yang diambilkan dari hasil Property Tax. Apabila yang terakhir ini yang dipilih maka di dalam Peraturan daerah yang berkaitan dengan penyandang disabilitas ditentukan bahwa pendanaan bagi penyandang disabilitas yang disediakan oleh pemerintah daerah ditentukan setiap tahun sekurang-kurangnya sekian persen dari hasil perolehan pajak hiburan, dan diatur dalam Peraturan Daerah Tentang Anggaran Pendapatan dan Belanja Daerah. Untuk daerah yang tidak memunyai potensi pajak hiburan maupun potensinya sangat kecil, maka dana bagi penyandang disabilitas dapat diberikan oleh pemerintah pusat dan dari sumber lain dengan besaran yang disesuaikan kebutuhan dan proporsional dengan memperhatikan kebutuhan lainnya.

\section{Penutup}

Berdasarkan paparan sebagaimana dikemukakan di atas maka dapat diketahui bahwa penyediaan dana terhadap penyediaan sarana dan prasarana bagi penyandang disabilitas adalah sangat urgen. Urgensi tersebut mencakup mengenai alasan-alasan sehingga perlu penyediaan dana bagi penyandang disabilitas dan penentuan macam kebutuhan yang perlu penyediaan dana.

Strategi penganggaran terhadap penyandang disabilitas tergantung kepada siapa yang bertanggung jawab terhadap urusan penyandang disabilitas, dalam konteks pembagian urusan antara pemerintah pusat dan pemerintah daerah maka urusan tersebut termasuk urusan yang didesentralisasikan ke daerah. Untuk itu daerah dapat menyediakan dari PAD yang berasal dari pajak hiburan dengan pola earmarking. Apabila hal tersebut belum mencukupi mengingat potensi pajak daerah yang tidak ada atau tidak memadai, maka untuk pendanaan penyandang disabilitas dapat disediakan oleh pemerintah pusat dan sumber pendanaan lain yang sah.

Strategi pengaturan yang dapat dilakukan terhadap penyediaan sarana dan prasarana bagi kaum difabilitas dapat dilakukan dengan menggunakan amandemen untuk memperluas pengalokasian langsung (earmarking) dana hasil dari pajak hiburan. Hal tersebut dipandang tepat karena di satu sisi pajak hiburan dikenakan terhadap layanan hiburan bagi masyarakat, di sisi lain diharapkan hasilnya juga dapat dinikmati oleh mereka yang kurang beruntung (penyandang disabilitas). Pola subsidiaritas ini tentu menjadi hal yang penting. Mengenai jumlah/ porsi alokasi dari hasil pajak hiburan tersebut dengan melihat ketiga contoh earmarking yang telah terjadi, maka kiranya bisa ditentukan batas minimal dari hasil pajak hiburan dengan melihat potensi pajak daerah. Selain itu juga perlu dilakukan pengaturan dalam undang-undang tersendiri bagi penyandang disabilitas yang di dalamnya memuat pengaturan pendanaan. Dalam menghimpun dana dari 
sumber lain juga dapat dilakukan dengan mengatur di dalam UndangUndang tentang Perseroan Terbatas untuk mengamandemen ketentuan mengenai CSR dan dan Undang-Undang Nomor 28 Tahun 2009 tentang Pajak Daerah dan Retribusi Daerah.

\section{Daftar Pustaka}

\section{A. Buku}

Bird, Richard M. and Slack, Eid, 2003, International Handbook of Land and Property Taxation, Massachusetts, USA: Edward Elgar Publishing, inc.

Booth, Wayne. C. et al, 2003, The Craft of The Research, Second Edition, Chicago: University of Chigago Press.

Friedmann, 1992, Empowerment: The Politics of Alternative Development, Cambridge Mass: Blackwell Publisher.

Istanto, F.Sugeng, 2007, Penelitian Hukum, Yogyakarta: CV. Ganda.

Kanter: Arlene S., 2015, The Development of Disability Rights Under International Law (From Charity to Human Rights), New York: Routledge.

Larry Schroeder, 2003, Fiscal Decentralization in South East Asia, Journal of Public Budgeting, Accounting \& Financial Mnagement, Vol.15 No.3, Academic Press.

Magnis, Franz, 1991, Etika Politik, Prinsip-Prinsip Dasar Kenegaraan Modern, Jakarta: Gramedia.

Marzuki, Peter Mahmud, 2007, Penelitian Hukum, Cetakan Ketiga, Jakarta: Kencana Prenada Media Group.

Pudyatmoko, Sri, 2009, Pengantar Hukum Pajak, Yogyakarta: Penerbit Andi.

Siahaan, Marihot Pahala, 2010, Pajak Daerah dan Retribusi Daerah, Jakarta: PT. Raja Grafindo Persada.

Suharto, Edi, 2011, Kebijakan Sosial Sebagai Kebijakan Publik, Bandung: Penerbit Alfabeta.

Suseno dan Magnis, Franz, 1991, Etika Politik, Prinsip-Prinsip Dasar Kenegaraan Modern, Jakarta: Gramedia.

Wijaya, I Putu, dkk, 2007, Kebijakan Pengaturan Perimbangan Keuangan dalam Konsepsi dan Perspektif Keadilan, Jurnal Hukum Udayana, Bali.

Yani, Ahmad, 2002, Hubungan Keuangan Antara Pemerintah Pusat dan Daerah di Indonesia, Jakarta: PT.Raja Grafindo Persada. 


\section{B. Lain-lain}

Direktorat Jenderal Perimbangan Keuangan, Departemen Keuangan Republik Indonesia. (http://www.djpk.kemenkeu.go.id), http://www.fiskal.depkeu.go.id/2010/m/edef-konten-viewmobile.asp?id, diunduh tanggal 12 Oktober 2015.

Edy Priyono, "Earmarking" Untuk Biayai Pendidikan Daerah, dalam http://www.akademika.or.id/arsip/Earmarking untuk Biayai Pendidikan Daerah. html, diunduh 14 Oktober 2015.

Konsorsium Nasional Untuk Hak Disabilitas, 2010, Membangun Kebijakan Publik ProPenyandang Disabilitas. 